\title{
PERHITUNGAN HARGA POKOK PRODUKSI KERUPUK DENGAN MENGGUNAKAN METODE FULL COSTING (Studi Kasus Pada UKM Kerupuk Cita Rasa Sidomulyo Barat - Pekanbaru)
}

\author{
Fifitri Ali*1, Annisha Harianti $^{2}$ \\ ${ }^{1,2}$ Politeknik Caltex Riau; Pekanbaru, \\ ${ }^{3}$ Program Studi Akuntansi, Politeknik Caltex Riau \\ e-mail: * ${ }^{1}$ fifitri@pcr.ac.id,, annisha@ alumni.pcr.ac.id
}

\begin{abstract}
Abstrak
Penelitian ini dilakukan untuk mengetahui perhitungan harga pokok produksi dengan menggunakan metode full costing dan mengetahui perbedaan perhitungan harga pokok produksi berdasarkan perhitungan dari UKM Kerupuk Cita Rasa. Setelah dilakukan perhitungan harga pokok produksi dengan menggunakan metode full costing terdapat adanya perbedaan dengan perhitungan yang dilakukan oleh UKM. Selisih perhitungan harga pokok produksi berdasarkan perusahaan dengan metode full costing per unit produk adalah sebesar Rp 9,90 untuk kerupuk Palembang dan Rp 3,42 untuk kerupuk nasi. Sedangkan secara keseluruhan perbedaan antara perhitungan berdasarkan UKM dengan perhitungan menggunakan metode full costing adalah sebesar Rp 13,32 per unit produk. Hal ini disebabkan karena pembebanan biaya overhead pada masing-masing produk lebih rinci. Perhitungan harga pokok produksi menurut perusahaan tidak memisahkan harga pokok produksi per produk, sedangkan perhitungan harga pokok produksi menggunakan metode full costing memisahkan harga pokok produksi masing-masing produk.
\end{abstract}

Kata kunci : Harga Pokok Produksi, Full Costing, Biaya Overhead

\begin{abstract}
This research was conducted to determine the calculation the cost of goods manufactured using the full costing method and to find out the difference in the calculation of the cost of goods manufactured based on UKM Kerupuk Cita Rasa. After calculating the cost of goods manufactured using the full costing method, there is a difference with the calculations made by the UKM. The difference in the calculation of the cost of goods manufactured based on the UKM using the full costing method per product unit is $R p 9.90$ for Palembang crackers and $R p 3.42$ for rice crackers. Meanwhile, the overall difference between the calculation based on UKM and the calculation using the full costing method is Rp 13.32 per product unit. This is because the imposition of more detailed overhead costs for each product. The calculation of the cost of goods manufactured according to the company does not separate the cost of goods manufactured per product, while the calculation of the cost of goods manufactured using the full costing method separates the cost of goods manufactured for each product.
\end{abstract}

Keywords : Cost of Goods Manufactured, Full Costing, Overhead Cost

\section{PENDAHULUAN}

Informasi biaya produksi merupakan hal penting untuk mengetahui biaya-biaya yang dikeluarkan dalam memproduksi suatu produk di perusahaan. Seiring dengan pesatnya perkembangan dunia dalam bidang usaha, semakin banyak pula usaha yang terus berkembang, maka semakin ketat pula persaingan dalam dunia bisnis apalagi usaha yang sejenis. perhitungan biaya berdasarkan process costing atau metode full costing yaitu metode yang menggunakan seluruh biaya produksi baik biaya yang 
bersifat tetap maupun biaya variabel ke dalam perhitungan harga pokok produksi seperti biaya bahan baku, biaya tenaga kerja langsung dan biaya overhead pabrik bersifat tetap maupun variabel. Permasalahan yang terjadi sekarang, banyak UKM yang tidak melakukan perhitungan secara rinci untuk menentukan harga pokok penjualan produk, salah satunya yang terjadi di UKM Kerupuk Cita Rasa.

UKM Kerupuk Cita Rasa adalah suatu industri yangbergerak dibidang produksi dan penjualan berupa kerupuk Palembang dan kerupuk nasi yang siap untuk dikonsumsi oleh umum dan UKM ini melakukan kegiatan produksinya setiap hari. Kegiatan yang dilakukan oleh UKM Kerupuk Cita Rasa ini adalah dimulai dari memproduksi, mencetak, mengukus, menjemur, menggoreng kemudian pembungkusan dan dilanjutkan dengan proses penjualan atau melakukan pemasaran. Selama ini UKM Kerupuk Cita Rasa tidak melakukan perhitungan secara rinci untuk harga pokok produksi per produk yang akan berguna untuk mengetahui biaya yang telah dikeluarkan untuk membuat kedua produk dan perhitungan harga pokok produksi tersebut juga berpengaruh untuk menentukan harga pokok penjualan produk. Perusahaan hanya menggunakan perhitungan secara tradisional dengan melibatkan perhitungan biaya bahan baku, biaya bahan penolong, biaya tenaga kerja langsung dan biaya listrik tanpa mempertimbangkan biaya yang lain seperti biaya overhead pabrik lainnya. Dalam perhitungan ini akan menyebabkan kurang akurat dalam penentuan harga pokok produksi yang sesungguhnya.

Untuk itu perusahaan harus mengetahui secara pasti berapa harga pokok produksi yang sebenarnya dengan memasukkan seluruh komponen biaya produksi. Perusahaan tidak berani untuk mengambil resiko jika kehilangan pelanggan atau konsumennya. Jadi untuk menghindari resiko tersebut, tentu saja perusahaan harus menggunakan perhitungan yang berbeda untuk mendapatkan hasil yang maksimal. Selain itu, jika perusahaan menetapkan harga per produk berdasarkan harga pasar tertinggi maka akan sulit bagi perusahaan untuk dapat bersaing dengan perusahaan lain yang memproduksi produk sejenis.

\section{Biaya}

Biaya mempunyai berbagai macam arti tergantung dari pemakai istilah tersebut. Menurut (Supriyono, 2011) membedakan biaya kedalam dua pengertian yang berbeda yaitu biaya dalam arti cost dan biaya dalam arti expense. Biaya dalam arti cost (harga pokok) adalah jumlah yang dapat diukur dalam satuan uang dalam rangka pemilikan barang dan jasa yang diperlukan oleh perusahaan, baik pada masa lalu maupun pada masa yang akan datang. Sedangkan beban (expense) adalah biaya yang dikorbankan atau biaya yang dikonsumsi untuk memperoleh pendapatan dalam suatu periode akuntansi tertentu.

Menurut (Bustami \& Nurlela, 2010) menyatakan biaya adalah pengorbanan sumber ekonomis yang dapat diukur dalam satuan uang yang telah terjadi atau kemungkinan akan terjadi untuk mencapai tujuan tertentu. Jika biaya ini masa pakai nya belum habis digolongkan sebagai aktiva yang dimasukkan kedalam neraca. Contohnya persedian produk dalam proses, persediaan produk selesai, perlengkapan (Supplies). Sedangkan beban (expense) adalah biaya yang telah memberikan manfaat. Biaya yang belum dinikmati dimasukkan ke dalam laba/rugi

Berdasarkan beberapa pengertian diatas, maka dapat disimpulkan bahwa biaya adalah pengorbanan yang dilakukan untuk mendapatkan manfaat sekarang atau masa 
depan, baik yang telah terjadi atau yang akan terjadi untuk manfaat tertentu atau untuk memperoleh suatu aktiva. Sedangkan beban adalah suatu biaya yang telah digunakan dan masa manfaatnya telah habis untuk memperoleh pendapatan

\section{Unsur-Unsur Biaya Produksi}

Menurut Mulyadi, (2015) biaya produksi terbagi menjadi tiga elemen biaya yaitu biaya bahan baku, biaya tenaga kerja dan biaya overhead pabrik atau biaya untuk menyelesaikan suatu produk.

1. Bahan Baku adalah bahan yang membentuk bagian menyeluruh menjadi produk jadi. Tenaga kerja adalah usaha fisik atau mental yang dikeluarkan oleh karyawan untuk mengolah suatu produk.

2. Biaya tenaga kerja adalah harga yang dibebankan untuk penggunaan tenaga kerja manusia tersebut.

3. Biaya overhead pabrik dikelompokkan menjadi tiga bagian yaitu:

a. Biaya bahan penolong adalah bahan yang tidak menjadi bagian produk jadi atau bahan meskipun menjadi bagian produk jadi tetapi nilai nya relatif kecil bila dibandingkan dengan harga pokok produksi tersebut.

b. Biaya tenaga kerja tidak langsung adalah tenaga kerja pabrik yang upahnya tidak dapat diperhitungkan secara langsung ke produk atau pesanan tertentu. Biaya tenaga kerja tidak langsung terdiri dari upah, tunjangan dan biaya kesejahteraanyang dikeluarkan untuk tenaga kerja tidak langsung tersebut.

c. Biaya reparasi dan pemeliharaan terdiri dari suku cadang (spare parts), biaya bahan baku habis pakai (factory supplies) dan harga perolehan jasa dari pihak luar perusahaan untuk keperluan perbaikan dan pemeliharaan emplasemen, perumahan, bangunan pabrik, mesin dan peralatan, kendaraan, perkakas laboratorium, dan aset lain yang digunakan untuk keperluan pabrik.

\section{Harga Pokok Produksi}

Menurut (Bustami \& Nurlela, 2010) Harga pokok produksi adalah kumpulan biaya produksi yang terdiri dari bahan baku langsung, tenaga kerja langsung dan biaya overhead pabrik yang ditambah denganpersediaan produk dalam proses awal kemudian dikurangi denganpersediaan produk dalam proses akhir. Sedangkan menurut (Witjaksono, 2013) harga pokok produksi adalah sejumlah nilai aktiva (asset), tetapi apabila selama tahun berjalan aset tersebut membantu memperoleh penghasilan, aset tersebut harus dikonversikan ke beban (expense).

Menurut Mulyadi (2009) harga pokok produksi adalah pengumpulan biaya produksi untuk setiap proses selama jangka waktu tertentu dan biaya produksi per satuan dihitung dengan cara membagi total biaya produksi selama periode tertentu dengan jumlah satuan produk yang dihasilkan dari proses tersebut selama jangka waktu yang bersangkutan. Dari pengertian-pengertian tersebut dapat diambil kesimpulan bahwa harga pokok produksi adalah biaya-biaya yang dikeluarkan dalam pengolahan bahan baku untuk menghasilkan suatu produk atau menjadi produk jadi selama periode akuntansi.

\section{Metode Full Costing}

Metode full costing adalah metode yang penentuan harga pokok produksi memperhitungkan semua unsur biaya-biaya produksi kedalam harga pokok produksi, yang masuk kedalam perhitungan metode ini terdiri dari biaya bahan baku, biaya tenaga 
kerja langsung dan biaya overhead pabrik baik yang variabel maupun tetap. Dalam metode full costing, biaya overhead pabrik baik yang tetap maupun yang variabel dibebankan ke produk yang diproduksi atas dasar tarif yang telah ditentukan di muka atau diawal, pada kapasitas normal atau dasar biaya overhead pabrik sesungguhnya. Oleh karena itu, overhead tetap melekat pada harga pokok persediaan produk dalam proses dan persediaan produk jadi yang belum laku terjual, dan baru dianggap sebagai biaya (unsur harga pokok penjualan).

\section{Karakteristik Metode Full Costing}

Menurut (Mursyidi, 2010) karakteristik Metode full costing sebagai berikut;

a) Perhitungan biaya produksi yang memasukkan biaya tetap dan biaya variable,

b) Laporan rugi laba disajikan dengan format tradisional,

c) Analisis biaya dilakukan oleh pihak internal untuk perhitungan biaya persediaan, penentuan laba dan pelaporan keuangan untuk pihak eksternal,

d) Menganut konsep biaya produk untuk perhitungan biaya produksi variabel dan biaya yang menganut konsep biaya periodik untuk perhitungan biaya produksi.

e) Laporan biaya untuk memenuhi pihak eksternal.

\section{Keunggulan Metode Full Costing}

Mulyadi (2012) ada 2 keunggulan dari metode full costing sebagai berikut:

a. Metode full costing akan berpengaruh pada laporan laba rugi perusahaan karena pembebanan seluruh biaya produksi tetap maupun biaya produksi variabel.

b. Metode full costing membebankan seluruh biaya produksi tetap dan biaya produksi variabel ke dalam produk.

\section{Kelemahan Metode Full Costing}

Menurut Mulyadi (2012) ada 2 kelemahan dari full costing sebagai berikut:

a. Metode full costing tidak cocok digunakan untuk melakukan perencanaan laba jangka pendek karena dalam perhitungan metode full costing ini memasukkan semua komponen biaya baik yang berperilaku tetap maupun variabel.

b. Data biaya yang disajikan dengan metode full costing tidak relevan untuk pengambilan keputusan jangka pendek bagi pihak manajemen.

\section{METODE PENELITIAN \\ Jenis dan Sumber Data}

Adapun sumber data yang digunakan dalam penelitian ini adalah data primer dan data sekunder. Data primer didapatkan langsung atau diperoleh langsung dari pengamatan dan wawancara langsung dengan pemilik UKM Kerupuk Cita Rasa. Datadata primer yang didapatkan seperti Sejarah perusahaan, biaya bahan baku, biaya tenaga kerja langsung, biaya overhead pabrik dan perhitungan tradisional yang dilakukan oleh perusahaan. Sedangkan data sekunder yaitu data yang diperoleh secara tidak langsung melalui media berupa dokumentasi tentang kegiatan produksi UKM Kerupuk Cita Rasa.

Jenis data yang digunakan dalam penelitian ini adalah data kualitatif, yaitu data yang diperoleh baik secara lisan maupun tertulis seperti gambaran singkat dan aktivitas usaha. Adapun daftar biaya yang digunakan dalam penelitian ini adalah sebagai berikut: 
Tabel 1. Data Biaya Produksi UKM Kerupuk Cita Rasa

\begin{tabular}{|c|c|}
\hline Jenis Biaya & Keterangan \\
\hline \multirow[t]{6}{*}{ 1. Biaya Bahan Baku } & a. Tepung Tapioka \\
\hline & b. Tepung Terigu \\
\hline & c. Ikan Tenggiri \\
\hline & d. Bawang Putih \\
\hline & e. Garam \\
\hline & f. $\quad$ Minyak Goreng \\
\hline \multirow[t]{3}{*}{ 2. Biaya Tenaga Kerja } & a. Upah Bagian Pembuatan Adonan \\
\hline & $\begin{array}{llll}\text { b. Upah Bagian Pencetak dan Pengukus } \\
\text { Kerupuk }\end{array}$ \\
\hline & $\begin{array}{l}\text { c. Upah Bagian Menjemur dan Menggoreng } \\
\text { Kerupuk }\end{array}$ \\
\hline \multirow{9}{*}{$\begin{array}{l}\text { 3. Biaya Overhead } \\
\text { Pabrik }\end{array}$} & a. Biaya penyusutan bangunan pabrik \\
\hline & b. Biaya penyusutan mesin pencetak kerupuk \\
\hline & c. Biaya penyusutan Mesin molen/penghapus \\
\hline & d. Biaya penyusutan mesin pengaduk kerupuk \\
\hline & e. Biaya penyusutan mesin kukusan uap \\
\hline & f. Biaya penyusutan blower \\
\hline & g. Biaya penyusutan mesin pompa air \\
\hline & h. Biaya penyusutan peralatan \\
\hline & i. Biaya listrik \\
\hline \multirow[t]{5}{*}{ Bahan penolong } & j. $\quad$ Penyedap rasa \\
\hline & k. Merk/label \\
\hline & 1. Kayu bakar \\
\hline & m. Plastik pembungkus \\
\hline & n. karet \\
\hline
\end{tabular}

\section{Teknik Pengumpulan Data}

Adapun teknik pengumpulan data yang akan digunakan dalam penelitian ini yaitu:

a. Wawancara

Menurut (Sarifillah, 2019) teknik wawancara adalah proses tanya jawab antara peneliti dengan subjek penelitian atau pemilik UKM Kerupuk Cita Rasa. Dalam penelitian ini, teknik pengumpulan data yang dilakukan dengan melakukan tanya jawab secara langsung kepada pemilik UKM Kerupuk Cita Rasa atau pemilik pabrik kerupuk yang berkaitan dengan perhitungan harga pokok produksi dan perkembangan perusahaan.

b. Dokumentasi

Menurut (Sarifillah, 2019) teknik dokumentasi adalah data pendukung yang dikumpulkan sebagai penguatan dari data observasi dan wawancara. Teknik ini dapat berupa catatan peristiwa yang sudah berlalu yang bisa berbentuk tulisan, gambar dan lain-lain. Dalam penelitian ini, teknik pengumpulan data yang dilakukan yaitu dengan mencari data atau informasi yang terkait dengan penelitian dan proses produksi kedua produk.

\section{Metode Analisis Data}


Menurut (Supriyono, 2011) analisis data yaitu proses menyusun secara sistematis data yang diperoleh dari hasil wawancara, catatan lapangan, dan dokumentasi dengan cara mengorganisasikan data kedalam kategori, menjabarkan ke dalam unit-unit, menyusun ke dalam pola, memilih mana yang penting dan yang akan dipelajari sehingga dapat membuat kesimpulan dan bisa dipahami oleh diri sendiri maupun orang lain. Tujuan dari teknik analisis data ini yaitu untuk menyederhanakan data sehingga lebih mudah untuk dimengerti.

\section{HASIL DAN PEMBAHASAN \\ Hasil}

\section{Perhitungan Biaya Bahan Baku}

Biaya bahan baku adalah biaya yang dikeluarkan untuk membeli bahan-bahan pembuatan kedua jenis produk kerupuk menjadi produk jadi. Biaya bahan baku juga merupakan unsur utama dari harga pokok produksi karena tanpa adanya biaya bahan baku suatu perusahaan tidak dapat memproduksi suatu produk yang akan dihasilkan. Dalam melakukan proses produksi 2 jenis kerupuk di UKM Kerupuk Cita Rasa yaitu kerupuk palembang menggunakan bahan baku tepung tapioka, tepung terigu, ikan tenggiri, bawang putih, garam dan minyak goreng. Sedangkan kerupuk nasi menggunakan bahan baku tepung tapioka, tepung terigu, pewarna makanan (gincu), bawang putih, garam dan minyak goreng.

\section{Perhitungan Biaya Tenaga Kerja Langsung}

Biaya tenaga kerja langsung adalah biaya upah yang dibayarkan kepada karyawan yang berhubungan langsung dengan proses produksi. Di UKM Kerupuk Cita Rasa jumlah tenaga kerja langsung berjumlah 7orang karyawan yang bekerja secara langsung di dalam pabrik dalam proses produksi. Adapun tenaga kerja yang berhubungan langsung dengan proses produksi antara lain yaitu bagian untuk pembuatan adonan berjumlah 2 orang karyawan, bagian untuk pencetakan dan pengukus kerupuk berjumlah 2 orang karyawan dan bagian untuk menjemur dan menggoreng kerupuk berjumlah 3 orang karyawan. Upah tenaga kerja langsung yang dibayarkan per bulan nya untuk masing-masing orang adalah sebesar Rp 1.500 .000 per bulan.

Tabel 2. Perhitungan Biaya Tenaga Kerja Langsung

\begin{tabular}{|l|l|l|l|l|}
\hline $\begin{array}{l}\text { Nama } \\
\text { karyawan }\end{array}$ & Gaji Per jam & Gaji Per Hari & Gaji Per Bulan & Gaji Per Tahun \\
\hline Salman & Rp 6.417 & Rp 51.333 & Rp 1.540.000 & Rp 18.480.000 \\
\hline Bagol & Rp 6.417 & Rp 51.333 & Rp 1.540.000 & Rp 18.480.000 \\
\hline Dadi & Rp 6.417 & Rp 51.333 & Rp 1.540.000 & Rp 18.480.000 \\
\hline Husen & Rp 6.417 & Rp 51.333 & Rp 1.540.000 & Rp 18.480.000 \\
\hline Prapto & Rp 6.417 & Rp 51.333 & Rp 1.540.000 & Rp 18.480.000 \\
\hline Ujang & Rp 6.417 & Rp 51.333 & Rp 1.540.000 & Rp 18.480.000 \\
\hline Engkus & Rp 6.417 & Rp 51.333 & Rp 1.540.000 & Rp 18.480.000 \\
\hline
\end{tabular}

\section{Perhitungan Biaya Overhead Pabrik}

Biaya overhead pabrik adalah biaya produksi yang merupakan selain biaya bahan baku langsung dan b iaya tenaga kerja langsung. Biaya overhead pabrik yang dikeluarkan oleh UKM Kerupuk Cita Rasa terdiri biaya penyusutan bangunan pabrik, 
biaya penyusutan mesin pencetak kerupuk, biaya penyustan mesin molen atau penghalus adonan, biaya penyusutan mesin pengaduk kerupuk, biaya penyusutan mesin kukusan uap, biaya penyusutan mesin pompa, biaya penyusutan blower, biaya penyusutan peralatan, biaya bahan penolong dan biaya listrik.

Tabel 3. Biaya Overhead Pabrik

\begin{tabular}{|l|l|l|}
\hline No & Keterangan & Total Biaya \\
\hline 1 & Biaya Penyusutan Aset Tetap & $\operatorname{Rp~25.875.000~}$ \\
\hline 2 & Biaya Penyusutan Peralatan & $\operatorname{Rp~} 2.774 .750$ \\
\hline 3 & Biaya Bahan Penolong & $\operatorname{Rp~} 100.764 .857$ \\
\hline 4 & Biaya Listrik Total & $\operatorname{Rp~7.290.000~}$ \\
\hline \multicolumn{2}{|c|}{$\quad$ Rp 136.704.607 } \\
\hline
\end{tabular}

\section{Pembahasan}

Perhitungan Harga Pokok Produksi Menurut Perusahaan Secara Tradisional

UKM Kerupuk Cita Rasa hanya menggunakan perhitungan secara tradisional dengan perhitungan yang sederhana dan belum merincikan seluruh biaya yang dikeluarkan untuk menentukan harga pokok produksi kedua produknya yaitu kerupuk Palembang dan kerupuk nasi. Dalam melakukan perhitungan harga pokok produksi UKM Kerupuk Cita Rasa hanya membebankan biaya untuk membeli bahan-bahan pembuatan kerupuk Palembang dan kerupuk nasi seperti biaya tepung tapioka, tepung terigu, ikan tenggiri, pewarna makanan (gincu), bawang putih, garam, minyak goreng, penyedap rasa, kayu bakar, merk/label, plastic pembungkus, karet dan gas. Biaya lain nya seperti biaya tenaga kerja langsung dan biaya listrik.

UKM Kerupuk Cita Rasa belum memasukkan seluruh biaya overhead pabrik yang timbul saat proses produksi kerupuk Palembang dan kerupuk nasi. Hal ini menyebabkan terjadi adanya ketidaktepatan dari perhitungan harga pokok produksi per unit produk yang dihasilkan oleh UKM Kerupuk Cita Rasa. Dan UKM Kerupuk Cita Rasa juga tidak pernah melakukan perhitungan per pembagian atau per setiap jenis produknya. Adapun perhitungan harga pokok produksi secara tradisional menurut UKM Kerupuk Cita Rasa untuk kerupuk Palembang dan kerupuk nasi adalah sebagai berikut:

Tabel 4. Perhitungan Secara Tradisional Menurut UKM Kerupuk Cita Rasa

\begin{tabular}{|l|l|l|}
\hline \multicolumn{1}{|c|}{ Keterangan } & \multicolumn{1}{|c|}{ Biaya (Rp) } & Total Biaya (Rp) \\
\hline Pengeluaran: & & \\
\hline Tepung Tapioka & 194.400 .000 & \\
\hline Tepung Terigu & 32.760 .000 & \\
\hline Ikan Tenggiri & 32.400 .000 & \\
\hline Gincu & 1.440 .000 & \\
\hline Bawang Putih & 18.000 .000 & \\
\hline Garam & 8.640 .000 & \\
\hline Minyak Goreng & 216.000 .000 & \\
\hline Penyedap Rasa & 9.792 .000 & \\
\hline Kayu Bakar & 23.142 .857 & \\
\hline Merk/label & 2.400 .000 & \\
\hline Plastik Pembungkus & 43.200 .000 & \\
\hline
\end{tabular}




\begin{tabular}{|l|l|l|}
\hline \multicolumn{1}{|c|}{ Keterangan } & \multicolumn{1}{|c|}{ Biaya (Rp) } & Total Biaya (Rp) \\
\hline Karet & 15.750 .000 & \\
\hline Gas & 6.480 .000 & \\
\hline Listrik & 7.290 .000 & \\
\hline Gaji Karyawan & 129.360 .000 & Rp 741.054.857 \\
\hline Total biaya pengeluaran & & \\
\hline
\end{tabular}

Dapat dilihat dari tabel 4 diatas merupakan perhitungan secara tradisional yang dilakukan oleh UKM Kerupuk Cita Rasa untuk kedua jenis produknya. Selanjutnya menghitung biaya per produk dengan membagi biaya tersebut sesuai dengan kebutuhan untuk membuat masing-masing produk dan menggunakan persentase alokasi berdasarkan jumlah unit produk yang nanti nya akan berguna untuk mengetahui berapa perbandingan perhitungan harga pokok produksi menurut perusahaan dan dengan menggunakan metode full costing.

\section{a. Kerupuk Palembang}

Tabel 5. Perhitungan harga pokok produksi kerupuk Palembang berdasarkan data UKM kerupuk cita rasa

\begin{tabular}{|c|c|c|c|}
\hline No & Keterangan & \multicolumn{2}{|c|}{ Biaya (Rp) } \\
\hline \multirow{8}{*}{$\begin{array}{l}\text { 1. Biaya bahan } \\
\text { baku }\end{array}$} & Tepung tapioca & 129.600 .000 & \\
\hline & Tepung terigu & 7.560 .000 & \\
\hline & Ikan tenggiri & 32.400 .000 & \\
\hline & Bawang putih & 14.400 .000 & \\
\hline & Garam & 6.480 .000 & \\
\hline & Minyak goreng & 151.200 .000 & \\
\hline & Air & - & \\
\hline & \multicolumn{2}{|c|}{ Total biaya bahan baku } & 341.640 .000 \\
\hline \multirow[t]{5}{*}{ 2. BTKL } & \multicolumn{3}{|c|}{ Upah karyawan didalam pabrik: } \\
\hline & $\begin{array}{l}\text { Upah bagian } \\
\text { pembuatan adonan }\end{array}$ & 25.872 .000 & \\
\hline & $\begin{array}{l}\text { Upah bagian pencetak } \\
\& \text { pengukus }\end{array}$ & 25.872 .000 & \\
\hline & $\begin{array}{l}\text { Upah bagian } \\
\text { menjemur dan } \\
\text { menggoreng }\end{array}$ & 38.808 .000 & \\
\hline & \multicolumn{2}{|c|}{ Total biaya tenaga kerja langsung } & 90.552.000 \\
\hline \multicolumn{4}{|l|}{ 3. BOP } \\
\hline \multirow{6}{*}{$\begin{array}{l}\text { Biaya } \\
\text { penolong }\end{array}$} & Penyedap rasa & 6.120 .000 & \\
\hline & Kayu bakar & 16.200 .000 & \\
\hline & Merk/label & 1.680 .000 & \\
\hline & Plastic pembungkus & 32.400 .000 & \\
\hline & Karet & 12.600 .000 & \\
\hline & \multicolumn{2}{|c|}{ Total biaya bahan penolong } & 69.000.000 \\
\hline \multirow[t]{2}{*}{ Biaya lain-lain } & Biaya listrik & 6.550 .413 & \\
\hline & \multicolumn{2}{|c|}{ Total biaya lain-lain } & 6.550.413 \\
\hline
\end{tabular}


b. Kerupuk Nasi

Tabel 6. Perhitungan harga pokok produksi kerupuk Nasi berdasarkan data UKM kerupuk cita rasa

\begin{tabular}{|c|c|c|c|}
\hline No & Keterangan & \multicolumn{2}{|c|}{ Biaya (Rp) } \\
\hline \multirow{8}{*}{$\begin{array}{l}\text { 1. Biaya bahan } \\
\text { baku }\end{array}$} & Tepung tapioca & 64.800 .000 & \\
\hline & Tepung terigu & 25.200 .000 & \\
\hline & Ikan tenggiri & 1.440 .000 & \\
\hline & Bawang putih & 3.600 .000 & \\
\hline & Garam & 2.160 .000 & \\
\hline & Minyak goreng & 64.800 .000 & \\
\hline & Air & - & \\
\hline & \multicolumn{2}{|c|}{ Total biaya bahan baku } & 162.000.000 \\
\hline \multirow[t]{5}{*}{ 2. BTKL } & \multicolumn{3}{|c|}{ Upah karyawan didalam pabrik: } \\
\hline & $\begin{array}{l}\text { Upah bagian } \\
\text { pembuatan adonan }\end{array}$ & 11.088 .000 & \\
\hline & $\begin{array}{l}\text { Upah bagian pencetak } \\
\text { \& pengukus }\end{array}$ & 11.088 .000 & \\
\hline & $\begin{array}{l}\text { Upah bagian } \\
\text { menjemur dan } \\
\text { menggoreng }\end{array}$ & 16.632 .000 & \\
\hline & \multicolumn{2}{|c|}{ Total biaya tenaga kerja langsung } & 38.808.000 \\
\hline 3. BOP & & & \\
\hline \multirow{7}{*}{$\begin{array}{ll}\text { Biaya } & \text { bahan } \\
\text { penolong } & \end{array}$} & Penyedap rasa & 3.672 .000 & \\
\hline & Kayu bakar & 6.942 .857 & \\
\hline & Merk/label & 720.000 & \\
\hline & Plastic pembungkus & 10.800 .000 & \\
\hline & Karet & 3.150 .000 & \\
\hline & Gas & 6.480 .000 & \\
\hline & \multicolumn{2}{|c|}{ Total biaya bahan penolong } & 31.764.857 \\
\hline \multirow[t]{2}{*}{ Biaya lain-lain } & Biaya listrik & 739.587 & \\
\hline & \multicolumn{2}{|c|}{ Total biaya lain-lain } & $\mathbf{7 3 9 . 5 8 7}$ \\
\hline \multicolumn{3}{|c|}{ Total biaya pengeluaran } & 233.312.444 \\
\hline \multicolumn{3}{|c|}{ Harga pokok produk per uni } & 216,03 \\
\hline
\end{tabular}

Setelah dilakukan melakukan perhitungan data pada penelitian ini maka diperoleh hasil bahwa adanya perbedaan perhitungan harga pokok produksi antara perhitungan secara tradisional oleh UKM Kerupuk Cita Rasa dengan perhitungan menggunakan metode full costing terletak pada biaya overhead tetap seperti biaya penyusutan. Sedangkan untuk biaya bahan baku dan biaya tenaga kerja langsung tidak ada perbedaan. Berdasarkan tabel 4.37 diatas dapat diketahui bahwa terdapat selisih antara perhitungan harga pokok produksi menurut UKM Kerupuk Cita Rasa dengan perhitungan harga pokok produksi menggunakan metode full costing untuk masing- 
masing produk. Harga pokok produksi per unit produk berdasarkan data UKM Kerupuk Cita Rasa adalah sebesar Rp 201,49 untuk kerupuk palembang dan Rp 216,03 untuk kerupuk nasi, sedangkan harga pokok produksi per unit produk dengan menggunakan metode full costing adalah sebesar Rp 211,39 untuk kerupuk Palembang dan Rp 219,45 untuk kerupuk nasi.

Tabel 5. Perbandingan Perhitungan UKM dan Full Costing

\begin{tabular}{|l|c|r|r|}
\hline \multicolumn{1}{|c|}{ Jenis Produk } & UKM & Full Costing & \multicolumn{1}{c|}{ Selisih } \\
\hline Kerupuk Palembang & Rp 201,49 & Rp 211,39 & Rp9,90 \\
\hline Kerupuk Nasi & $\operatorname{Rp~216,03~}$ & $\operatorname{Rp~219,45~}$ & $\operatorname{Rp~3,42}$ \\
\hline Total & $\operatorname{Rp~417,52~}$ & $\operatorname{Rp~430,84~}$ & $\operatorname{Rp~13,32~}$ \\
\hline
\end{tabular}

Sari tabel 5 diatas juga dapat dilihat bahwa terdapat selisih perhitungan antara harga pokok produksi secara tradisional yang dilakukan oleh UKM Kerupuk Cita Rasa dengan harga pokok produksi dengan menggunakan metode full costing untuk masingmasing produk kerupuk yang diproduksi. Untuk kerupuk Palembang terdapat selisih sebesar Rp 9,90 per unit kerupuk sedangkan untuk kerupuk nasi terdapat selisih sebesar Rp 3,42 per unit kerupuk.

\section{KESIMPULAN}

Berdasarkan hasil penelitian yang telah dilakukan di UKM Kerupuk Cita Rasa, maka dapat ditarik beberapa kesimpulan sebagai berikut:

1. UKM Kerupuk Cita Rasa dalam melakukan perhitungan harga pokok produksi nya masih menghitung secara tradisional.

2. Harga pokok produksi menggunakan metode full costing untuk kerupuk Palembang adalah sebesar Rp 211,39 per unit produk sedangkan harga pokok produksi untuk kerupuk nasi adalah sebesar $\mathrm{Rp} 219,45$ per unit produk.

3. Harga pokok produksi yang dilakukan oleh UKM Kerupuk Cita Rasa secara keseluruhan baik kerupuk Palembang dan kerupuk nasi per unit adalah sebesar Rp 417,52 sedangkan harga pokok produksi yang dihitung dengan menggunakan metode full costing secara keseluruhan untuk kerupuk Palembang dan kerupuk nasi adalah sebesar Rp 430,84. Sehingga terdapat selisih secara keseluruhan untuk produk kerupuk Palembang dan kerupuk nasi per unit adalah sebesar Rp 13,32.

\section{SARAN}

Berdasarkan hasil penelitian yang telah dilakukan di UKM Kerupuk Cita Rasa, maka peneliti memberikan beberapa saran yaitu sebagai berikut:

1. UKM Kerupuk Cita Rasa sebaiknya melakukan perhitungan harga pokok produksi setiap jenis produknya secara akurat dan tepat

2. Dalam melakukan perhitungan harga pokok produksi UKM Kerupuk Cita Rasa dapat menggunakan metode full costing, karena dengan menggunakan metode ini perusahaan dapat mengetahui dan merincikan semua biaya-biaya yang dikeluarkan dalam melakukan proses produksi.

3. UKM Kerupuk Cita Rasa sebaiknya juga memperhatikan biaya-biaya lain yang timbul dalam proses produksi terutama biaya overhead pabrik tetap 


\section{DAFTAR PUSTAKA}

Astuty. (2014). Akuntansi Manajemen: Informasi Bagi Manajer untuk Perencanaan, Pengendalian dan Pengambilan Keputusan Bisnis. Bandung: Citapustaka Media Perintis.

Badriyah. (2015). Buku Pintar Akuntansi Biaya untuk Orang Awam. Jakarta: HB.

Bustami, \& Nurlela. (2010). Akuntansi Biaya Edisi Kedua. Jakarta: Mitra Wacana Kencana.

Firmansyah. (2013). Akuntansi Biaya Gampang. Bandung: Dunia Cerdas.

Hansen, \& Mowen. (2006). Akuntansi Manajemen. Jakarta: Salemba Empat.

Mulyadi. (2010). Akuntansi Biaya. Yogyakarta: Yogyakarta: Unit Penerbitan dan Percetakan Sekolah.

Mulyadi. (2015). Akuntansi Biaya Edisi Kelima. Yogyakarta: UPP - STIM YKPN.

Mursyidi. (2010). Akuntansi Dasar. Bogor: Ghalia Indonesia.

Nugroho, B. (2018). Analisis Penentuan Harga Pokok Produksi Jamu dengan Menggunakan Metode Full Costing (Studi Kasus di Usaha Mikro Jamu Bu Tini Yogyakarta). Universitas Sanata Dharma.

Raiborn, \& Kinney. (2011). Akuntansi Biaya. Jakarta: Salemba Empat.

Rudianto. (2013). Akuntansi Manajemen. Jakarta: Erlangga.

Sarifillah, N. (2019). Analisis perhitungan harga pokok produksi pada usaha mikro kecil dan menengah tahu Bapak Paiman. Institut Agama Islam Negeri Surakarta.

Suhayati, E. (2009). Akuntansi Keuangan Edisi Pertama. Graha Ilmu.

Supriyono. (2011). Akuntansi Biaya: Perencanaan dan Pengendalian Biaya serta Pembuatan Keputusan Edisi 2. Yogyakarta: BPFE - Yogyakarta.

Witjaksono. (2013). Akuntansi Biaya. Edisi Revisi. Jakarta: Graha Ilmu. 